\title{
PENINGKATAN RECOVERY EMAS DI CARBON IN LEACH PLANT PT. ANTAM TBK UNIT BISNIS PERTAMBANGAN EMAS PONGKOR, JAWA BARAT (STUDI KASUS KADAR BIJIH 3,5 - 4,5 GPT DI PLANT 1)
}

\author{
Nurhakim Zafar $^{1}$, Sudesno. Yudhistira ${ }^{2}$, Adiputra. Hoppy ${ }^{2}$ \\ ${ }^{1}$ Metallurgy Assistant Manager - Unit Bisnis Pertambangan Emas Pongkor PT Antam Tbk \\ ${ }^{2}$ Metallurgy Junior Engineer - Unit Bisnis Pertambangan Emas Pongkor PT Antam Tbk
}

\begin{abstract}
ABSTRAK
Sejarah pengolahan mineral emas di Unit Bisnis Pertambangan Emas (UBPE) Pongkor PT Antam Tbk menunjukkan adanya tren menurunnya kadar bijih. Meskipun demikian, metallugist di UBPE Pongkor PT Antam Tbk secara berkelanjutan mencari berbagai penyebab dan cara untuk meningkatkan nilai recovery Plant walaupun kadar bijih yang cenderung menurun. Berdasarkan hasil pengolahan data terhadap Plant 1 dan Plant 2 di UBPE Pongkor, menunjukkan adanya potensi perbaikan di area Plant 1 UBPE Pongkor PT Antam Tbk. Makalah ini akan berfokus pada pengurangan kadar emas dalam sand tailing saat kadar bijih antara 3,5 sampai 4,5 gram per ton (gpt) di Plant 1 dalam rentang 2 bulan. Berdasarkan hasil analisa data yang diperoleh dengan menggunakan metode Anova, diperoleh hasil bahwa fraksi halus, kadar sianida, dan waktu tinggal slurry adalah hal - hal yang paling berpengaruh dalam proses pengolahan emas di UBPE Pongkor. Serangkaian perbaikan dan inovasi dilakukan untuk menyelesaikan masalah ini, yaitu dengan cara memodifikasi distribusi ukuran grinding ball, mengatur waktu mixing dan injeksi sianida dalam tangki, serta mengatur waktu dan memonitoring waktu tinggal slurry di dalam tangki leaching dan CIL.

Berdasarkan hasil perbaikan dan inovasi yang dilakukan, terlihat bahwa nilai recovery plant meningkat dari sebelumnya $89,4 \%$ menjadi $92,7 \%$. Hal ini diperoleh dari nilai perbandingan distribusi ukuran bola 1 : 2 untuk grinding ball 40-60 $\mathrm{mm}$ dan $60-80 \mathrm{~mm}$. Sementara itu, penyesuaian terbaik kadar CN adalah 600 - 650 ppm ditambah dengan optimalisasi injeksi sianida menggunakan pompa dosing sehingga dapat mengurangi waktu mixing sianida yang $3 \mathrm{x}$ sehari menjadi $1 \mathrm{x}$ sehari dan menurunkan kadar $\mathrm{CN}$ dari 1,23 menjadi $1,13 \mathrm{~kg} \mathrm{NaCN} /$ ton bijih. Berdasarkan hasil pengaturan mill feeder dan pompa slurry, waktu tinggal di tangki leaching dari 51 jam menjadi 60 jam.
\end{abstract}

Kata Kunci : Emas, recovery, fraksi halus, sianida, waktu tinggal slurry

\begin{abstract}
History of mineral processing at Gold Business unit at PT Antam Tbk shows a consistent trend of decreasing grade due to intensive mining operations. Therefore, The Metallurgist PT Antam Tbk Gold Business Unit is looking for roots caused and solutions to raise up plant recovery although the grade of gold declined. After deep data analyzing process at plant $1 \& 2$, it's shown that plant 1 at Gold Business Unit PT Antam Tbk have a room for recovery improvement. This research focus on reducing sand tailing to improved gold recovery at feed grade between 3.5 and $4.5 \mathrm{ppm}$ at plant 1 . Deep analysis was applied to processing big data from the plant using ANOVA Methode, it's shown that fine fraction, Cyanide and slurry residence time were the major factor of gold recovery. Series improvement were applied to solved this problem, such as modifying grinding ball particle size distribution, adjusting cyanide feeding on leaching thank based on feed grade, and monitoring slurry residence time.
\end{abstract}


It was observed that the plant plant 1 recovery was increasing from $89,4 \%$ to $92.7 \%$. The best grinding ball particle size distribution was $1: 2$ for 50 \& $80 \mathrm{~mm}$ grinding ball. While the best applied cyanide concentration was between 600 - 650 ppm with some modification to improve process control of cyanide feeding. It's shown that cyanide mixing process was decreased from 3 times a day to only one a day and also the cyanide consumption was reduced from 1.23 to $1.13 \mathrm{~kg} /$ ton ore. Some modification also carried out to increase slurry residence time. It's proved that by applying the improvement it's shown that the slurry residence time rose from $50 \mathrm{~h}$ to $61 \mathrm{~h}$.

Keywords : gold, recovery, fine fraction, cyanide, residence time.

\section{A. PENDAHULUAN}

\section{A.1. Latar Belakang dan Tujuan}

PT Antam Tbk UBPE Pongkor berdiri sejak tahun 1994 hingga kini telah mengalami masa jayanya dan kini tetap beroperasi dengan kadar yang terus menurun. Pengolahan emas di UBPE Pongkor menggunakan proses carbon in leach (CIL) yang terus dilakukan inovasi dan perbaikan berkelanjutan untuk meningkatkan performa recovery pengolahan. Berdasarkan persamaan (1) terlihat, nilai recovery sangat dipengaruhi oleh nilai emas di sand tailing.

$$
\text { Rec. Emas }(\%)=\frac{\Delta L D P+\text { Realisasi Logam }}{\Delta L D P+\text { Realisasi logam }+ \text { Emas sand tailing }}
$$

Terlihat bahwa semakin besar nilai emas dalam sand tailing, maka semakin rendah nilai recovery pengolahan. sehingga perlu dilakukan perbaikan terus menerus untuk meminimalisir emas yang terdapat dalam sand tailing dan meningkatkan nilai recovery secara berkelanjutan.

\section{A.2. Pendekatan Pemecahan Masalah}

Pengumpulan dan analisa data diterapkan dalam memilih target area perbaikan dan dianalisa faktor yang paling berpengaruh dalam proses. Berdasarkan data September tahun 2018 sampai dengan Januari 2019 menunjukkan nilai rata - rata emas sand tailing Plant 1 (P1) sebesar 0,49 gram per ton (gpt) sedangkan pada Plant 2 (P2) sebesar 0,41 gpt dari batas maksimal adalah 0,51 gpt.

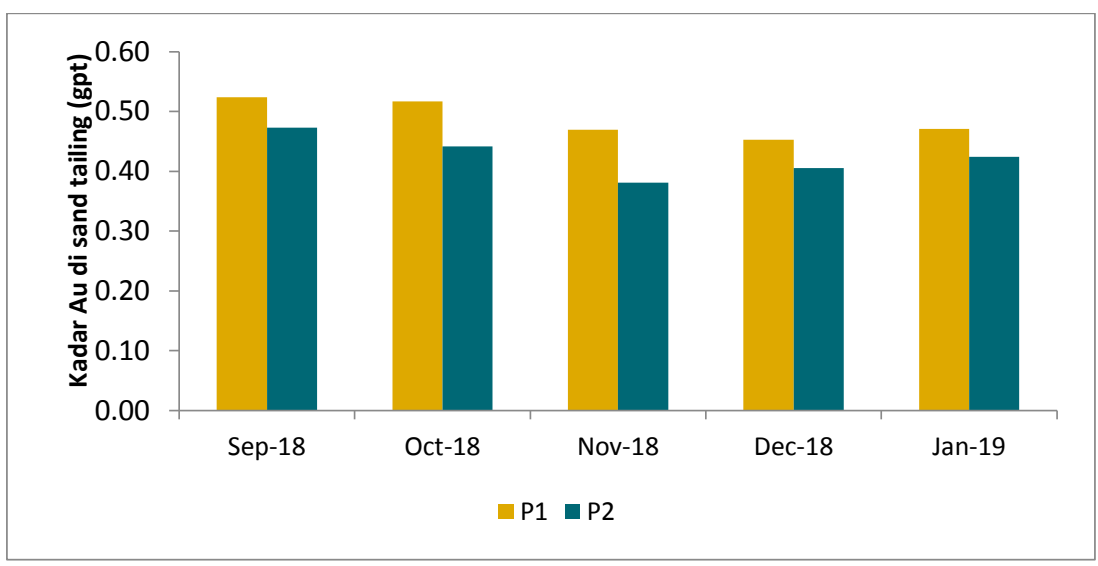

Gambar 1. Grafik Emas dalam sand tailing bulan September 2018 - Januari 2019 pada Plant 1 (P1) dan Plant 2 (P2) 
Berdasarkan gambar 1, terlihat kadar emas sand tailing P1 lebih tinggi dari Plant 2 sehingga masih dapat dioptimalkan. Selanjutnya, jika dioptimalkan. Diketahui bahwa nilai standar sand tailing maksimal yang dikandung dalam emas sand tailing di UBPE Pongkor adalah 0,51 gpt.

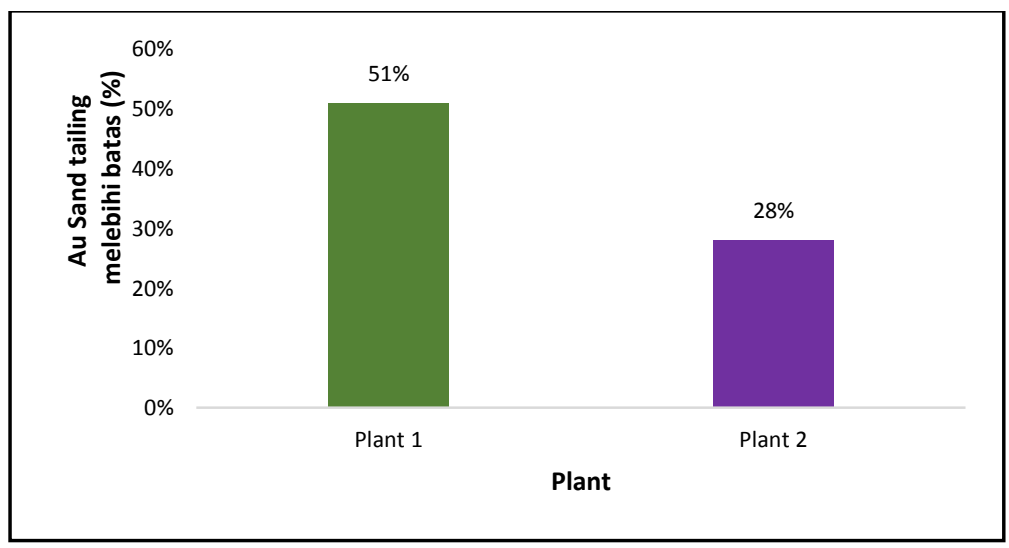

Gambar 2. Grafik perbandingan persentase penyimpangan kadar emas sand tailing di Plant 1 dan Plant 2

Gambar 2. memperkuat kondisi bahwa P1 memiliki potensi untuk diperbaiki. Oleh karena itu, Plant 1 dipilih sebagai target perbaikan, sehingga tema yang dipilih yaitu, peningkatan recovery Plant 1 di UBPE Pongkor. Kemudian metallurgist melakukan analisa data dengan mengelompokkan kadar feed masuk pabrik seperti yang disajikan dalam gambar 3.

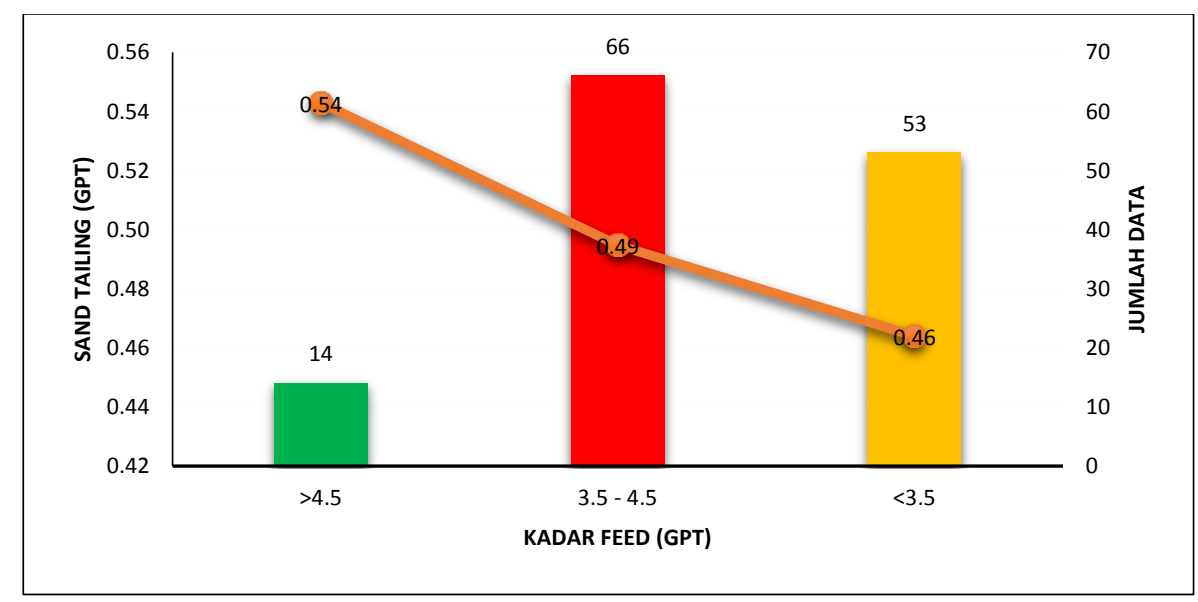

Gambar 3. Grafik perbandingan frekuensi kadar Au berdasarkan frekuensi kejadia kadar rata - rata sand tailing emas September 2018 - Januari 2019 di Plant 1

Terlihat berdasarkan data yang diperoleh, mayoritas kadar feed yang masuk ke Plant 1 adalah 3,5-4,5 gpt dengan frekuensi sebanyak 66x dan nilai sand tailing 0,49 gpt. Oleh karena itu, maka dipilihkan target feed 3,5 - 4,5 gpt. Acuan target juga dibuat sebagai salah satu pemacu metallurgist dalam bekerja. Berdasarkan histori data tahun 2018 yang disajikan dalam gambar 4, terlihat bahwa kondisi feed pabrik yang paling cocok dan sesuai dengan target adalah januari 2018 dengan nilai sand tailing 0,39 gpt atau recovery sebesar $89,4 \%$. 


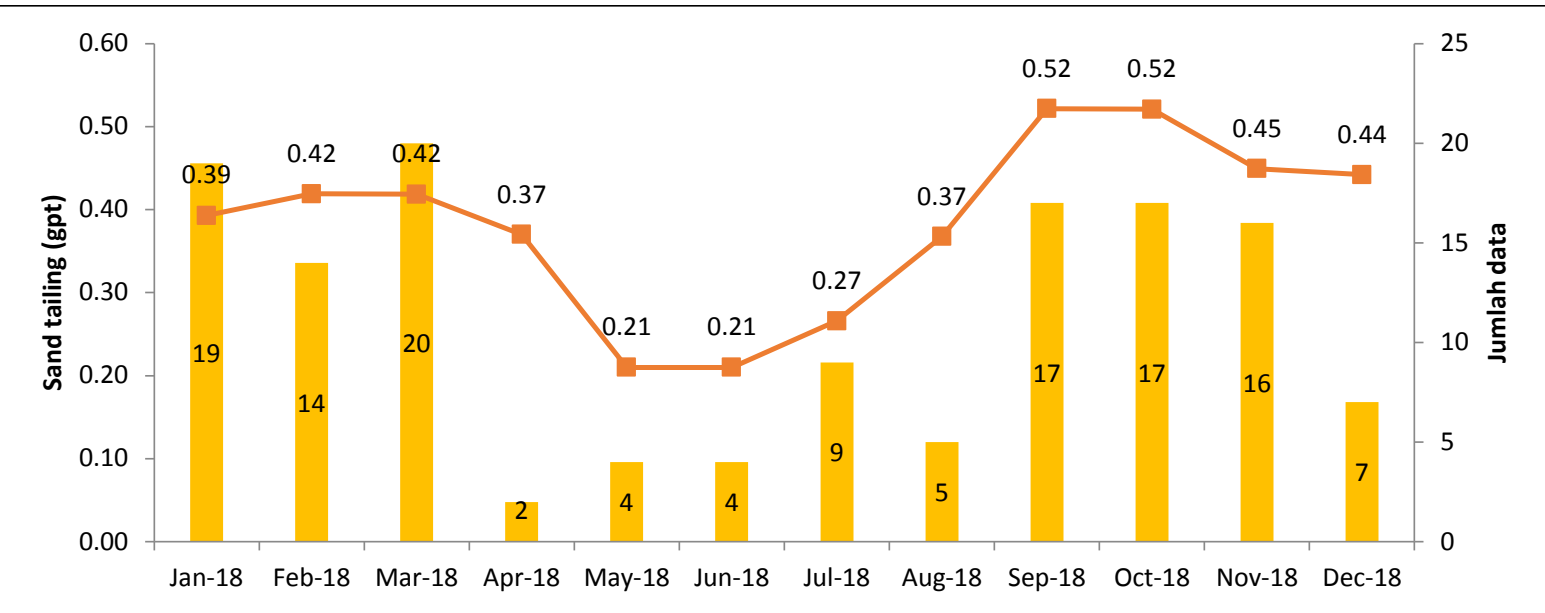

Gambar 4. Grafik perbandingan emas di sand tailing dan frekuensi kejadian kadar feed 3,5 - 4,5 gpt sepanjang 2018

Oleh karena itu, fokus perbaikan dalam penelitian kali ini adalah peningkatan recovery emas di pengolahan emas CIL PT Antam pada Plant 1 di kadar emas 3,5 sampai 4,5 gpt dengan target sand tailing 0,39 gpt atau recovery $90.63 \%$.

\section{B. METODOLOGI PEMECAHAN MASALAH}

\section{B.1. Analisa Faktor - faktor berpengaruh}

Diketahui bahwa proses pengolahan emas di UBPE Pongkor menggunakan metode Leaching - CIL yang tentunya dipengaruhi oleh berbagai parameter, fraksi halus, kadar sianida dan waktu tinggal slurry. Ketiga faktor ini diuji dengan metode anova dan diperoleh faktor paling berpengaruh terhadap sand tailing / recovery emas yang disajikan pada tabel 1,2 dan 3.

Tabel 1. Jumlah data Anova

\begin{tabular}{lcc}
\multicolumn{1}{c}{ CN (ppm) } & Total Row & N Row \\
\hline$<650$ & 19,74 & 42 \\
$650-700$ & 24,3 & 51 \\
$>700$ & 15,83 & 39 \\
\hline Fraksi Halus -200\# & Total Row & N Row \\
\multicolumn{1}{c}{$(\%)$} & & \\
\hline$<80 \%$ & 57.28 & 126 \\
$>80 \%$ & 2.47 & 6 \\
\hline \multicolumn{1}{c}{ Waktu Tinggal } & Total Row & N Row \\
\hline$<48$ jam & 25.05 & 52 \\
$>48$ jam & 34.82 & 80 \\
\hline
\end{tabular}


Tabel 2. Hasil pengolahan data

\begin{tabular}{|c|cccc|}
\hline Source of Variation & Sum of Squares & Degrees of Freedom Mean Square & $\mathrm{F}_{0}$ \\
\hline CN & 0,127203807 & 2 & 0,063601904 & 18,97 \\
Within samples & 0,41212 & 129,00 & 0,003194741 & \\
Error & 0,86523 & 258 & 0,003353597 & \\
Total & 1,40 & 131,00 & & \\
\hline
\end{tabular}

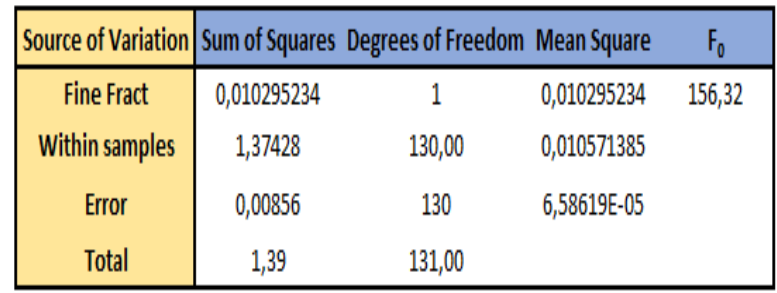

\begin{tabular}{|c|cccc|}
\hline Source of Variation & Sum of Squares & Degrees of Freedom Mean Square & $F_{0}$ \\
\hline Waktu tinggal & 0,06797 & 1 & 0,067974463 & 14,91 \\
Within samples & 0,74402 & 130,00 & 0,005723229 & \\
Error & 0,59256 & 130 & 0,004558147 & \\
Total & 1,40 & 131,00 & & \\
\hline
\end{tabular}

Tabel 3. Urutan faktor penyebab dominan

\begin{tabular}{ccccc}
\hline \multirow{2}{*}{ No } & Penyebab dominan & \multicolumn{2}{c}{ Faktor } & \\
\cline { 3 - 4 } & Sand tailing & Fo & F & Kesimpulan \\
\hline 1 & Fraksi halus & $\mathbf{1 5 6 , 3 1 6}$ & $\mathbf{6 , 8 3}$ & Sangat Mempengaruhi \\
2 & Reagen CN & $\mathbf{1 8 . 9 7}$ & $\mathbf{4 . 7 7}$ & Mempengaruhi \\
3 & Waktu tinggal & $\mathbf{1 4 , 9 1 3}$ & $\mathbf{6 , 8 3}$ & Mempengaruhi \\
\hline
\end{tabular}

Berdasarkan tabel 1,2 dan 3, terlihat bahwa nilai $\mathrm{F}_{\mathrm{o}}$ lebih besar daripada $\mathrm{F}$ sehingga dapat disimpulkan bahwa faktor tersebut memengaruhi nilai sand tailing/recovery. Oleh karena itu, diperoleh kesimpulan bahwa fraksi halus adalah faktor yang paling dominan memengaruhi proses, diikuti oleh sianida dan waktu tinggal di urutan 2 dan 3.

\section{HASIL DAN PEMBAHASAN}

Berdasarkan analisa anova terhadap ketiga faktor tersebut, dan diskusi pengalaman lapangan serta diimbangi dengan studi literatur, serangkaian perbaikan dan improvement dilaksanakan dan disajikan pada subbab 3.1, 3.2 dan 3.3.

\section{C.1. Peningkatan Fraksi Halus}

Sebelum perbaikan dilakukan, diketahui bahwa nilai fraksi halus -200\# dari P1 hanya mencapai $77,13 \%$ ( $<80 \%$ ). Berdasarkan hasil ball surveying (gambar 5a.) Dengan komposisi grinding ball didominasi oleh $60-80 \mathrm{~mm}$ seperti yang ditunjukkan oleh gambar 5b. menunjukkan bahwa operasional ball mill 01 tidak efektif karena gaya impak lebih besar dari gaya gerus karena ball mill 01 didominasi ukuran besar $(60-80 \mathrm{~mm})$ sebanyak $83 \%{ }^{(1)}$. 

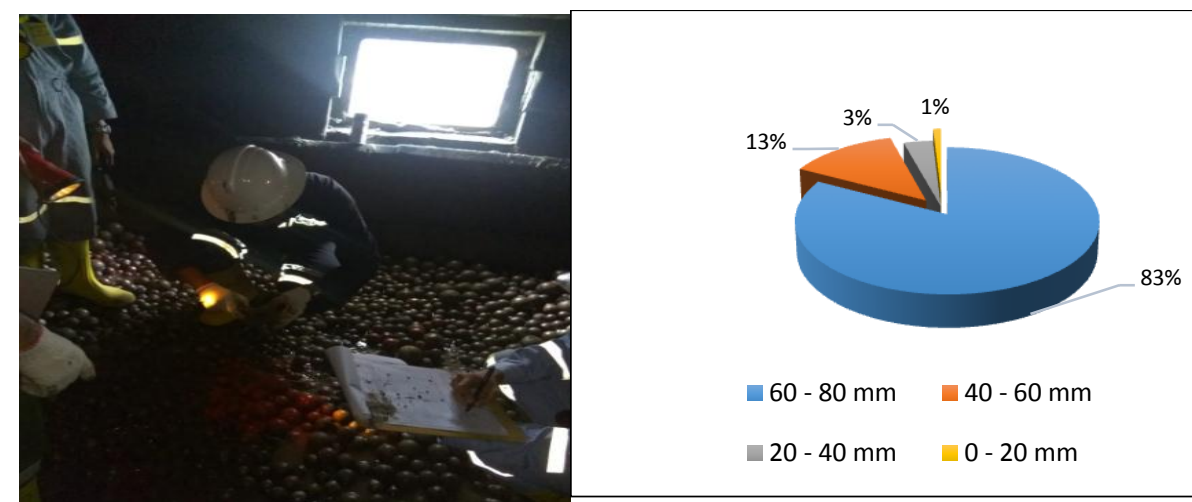

$$
\begin{aligned}
& 60-80 \mathrm{~mm} \quad 40-60 \mathrm{~mm} \\
& 20-40 \mathrm{~mm} \quad 0-20 \mathrm{~mm}
\end{aligned}
$$

Gambar 5. Ball Surveying (kiri), kondisi distribusi bola baja sebelum perbaikan (kanan)

Berdasarkan kondisi ini maka dilakukan blending bola baja dengan menambahkan bola ukuran yang lebih kecil, sehingga diperoleh hasil perbaikan yang ditunjukkan oleh gambar 6 . Terlihat bahwa nilai komposisi ukuran bola baja berukuran 40 - $60 \mathrm{~mm}$ meningkat menjadi 33\% atau perbandingannya dengan bola baja $60-80 \mathrm{~mm}$ menjadi $1: 2$, hal ini mengindikasikan adanya peningkatan daya gerus ${ }^{(1,2)}$. sehingga fraksi halus meningkat seperti yang dibuktikan dari data pasca perbaikan, nilai fraksi -200\# mencapai 83,77\% (gambar 7).

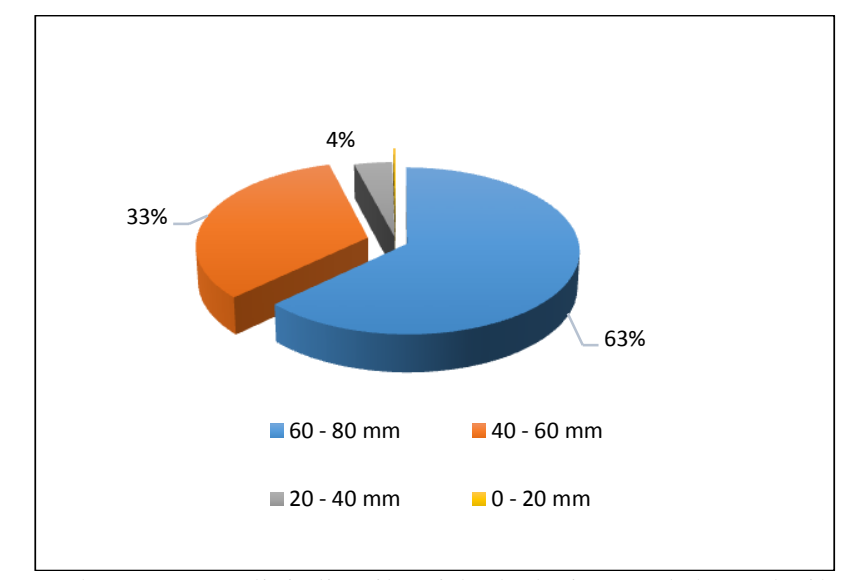

Gambar 6. Kondisi distribusi bola baja setelah perbaikan

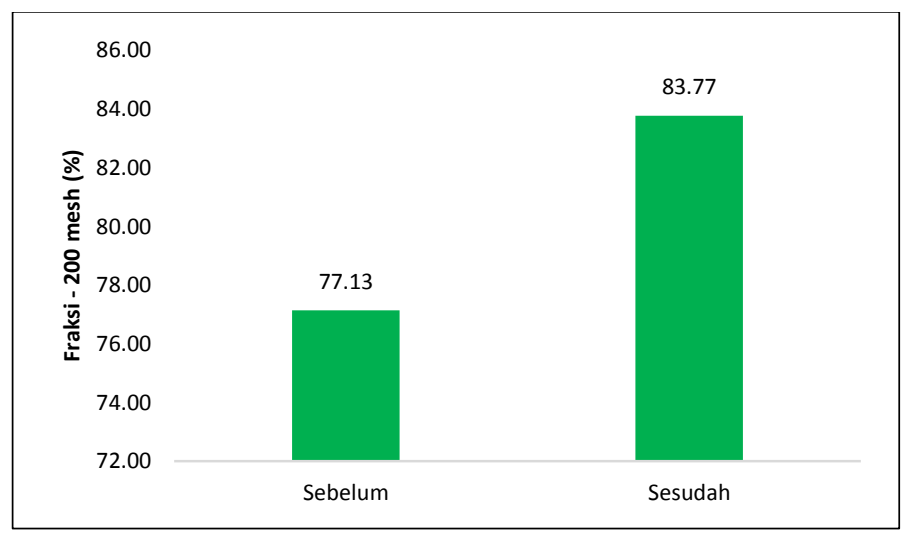

Gambar 7. Kondisi fraksi -200\# slurry setelah perbaikan 


\section{C.2. Optimasi Sianidasi}

Improvement yang dilakukan untuk mengefektifkan penggunaan sianida adalah dengan mengatur kadar sianida berdasarkan kadar feed yang masuk serta memodifikasi proses sianidasi dengan metode injeksi menggunakan pompa dosing serta menggunakan distributor $\mathrm{CN}$ untuk mengatur $\mathrm{CN}$ yang masuk ke dalam tangki leaching. Kegiatan dan gambar alat perbaikan ditunjukkan oleh gambar 8 dan 9.

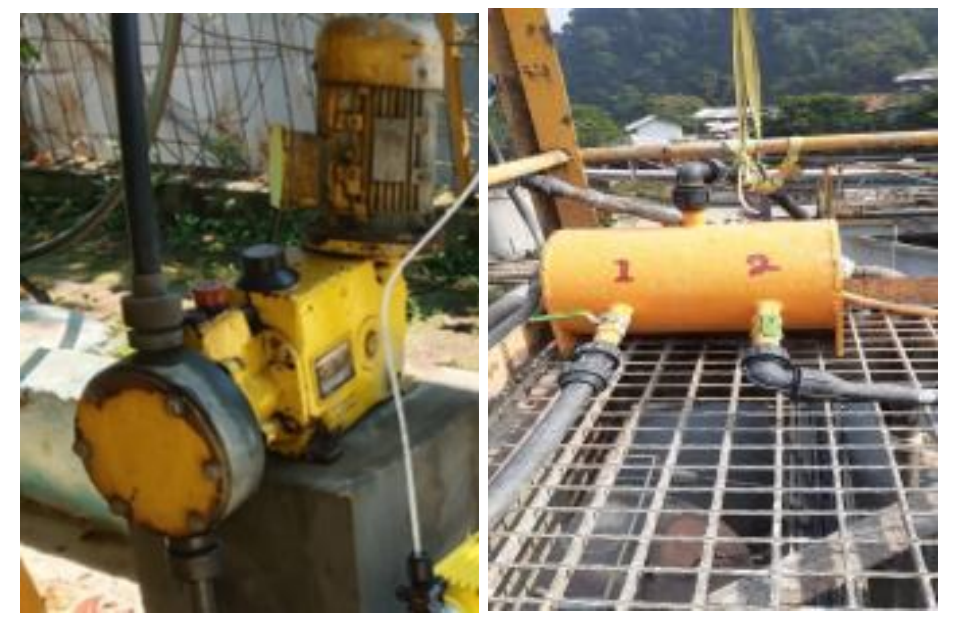

Gambar 8. Pompa dosing CN (kiri) dan distributor CN (kanan)

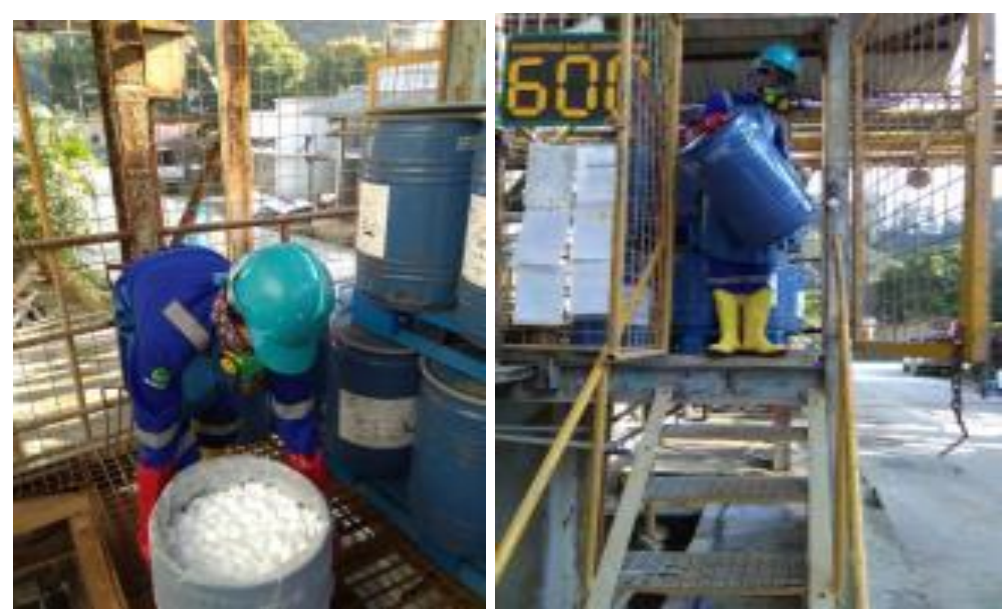

Gambar 9. Proses mixing Sianida

Hasil improvement ini, memudahkan operator dalam mixing sianida yang tadinya harus melakukan mixing setiap shift, kini hanya dilakukan proses mixing sianida di pagi hari yang tentunya lebih aman bagi operator. Sementara itu, gambar 10 dan 11 menunjukkan proses sebelum dan setelah pengaturan kadar $\mathrm{CN}$, terlihat bahwa penyesuaian kadar $\mathrm{CN}$ yang paling tepat tidak memengaruhi reaksi kimia terhadap pelarutan Emas oleh $\mathrm{CN}$, terlihat juga penurunan kadar sianida dari rata - rata selama September - Januari 719 ppm menjadi 656 ppm (Februari - Maret). Dampak dari penurunan kadar CN ini adalah adanya penurunan dosis $\mathrm{CN}$ yang sebelumnya $1,23 \mathrm{~kg} / \mathrm{ton}$ bijih menjadi $1,13 \mathrm{~kg} / \mathrm{ton}$. 

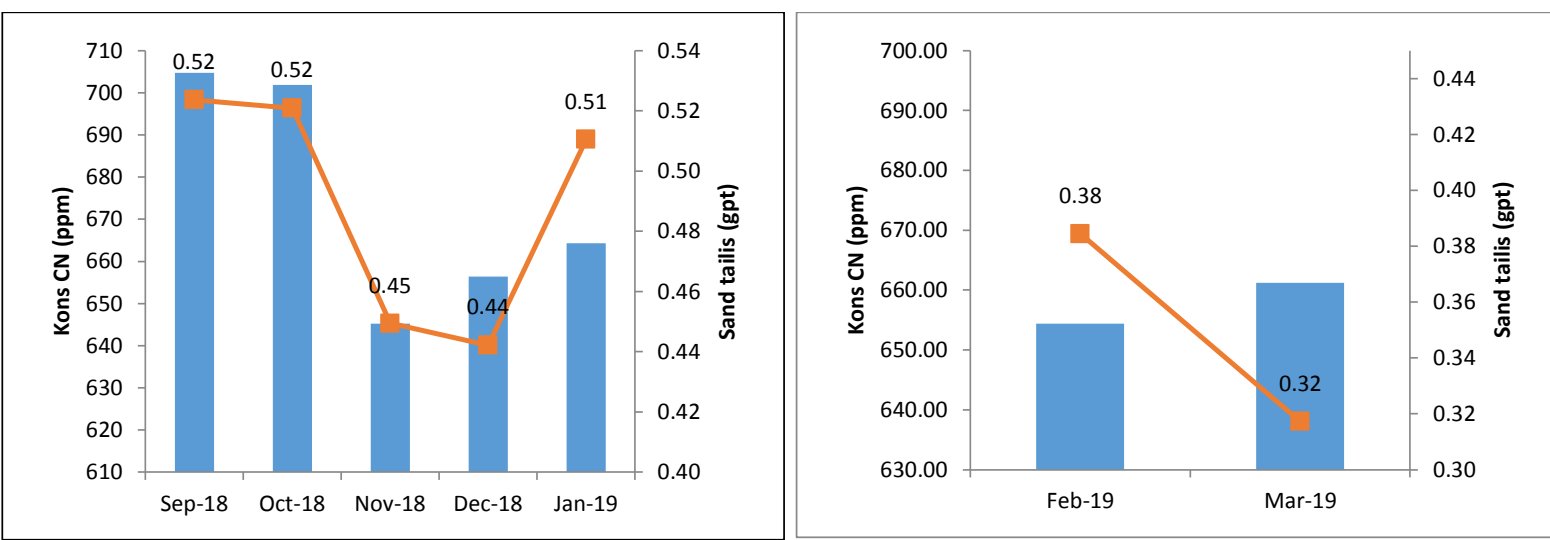

Gambar 10. Perbandingan sand tailing dan CN sebelum (kiri) dan sesudah (kanan) perbaikan

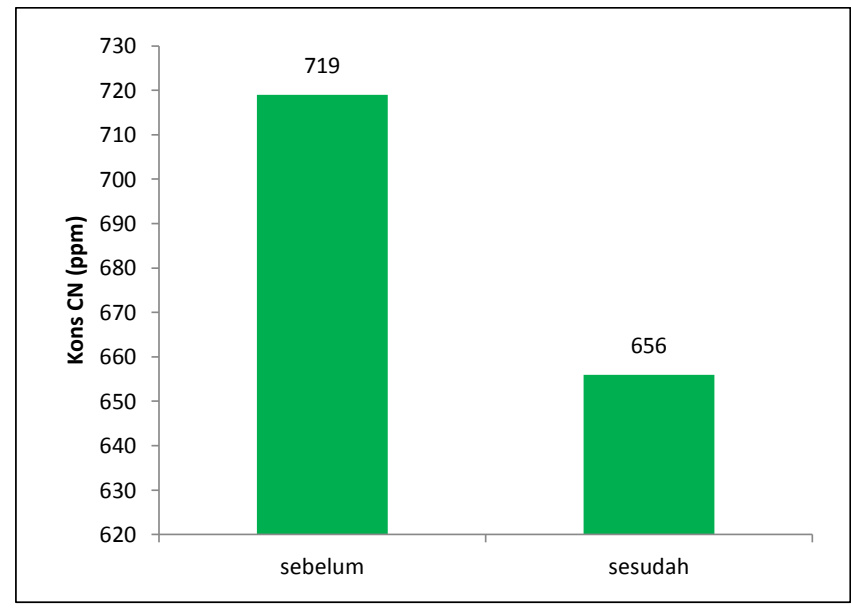

Gambar 11. Perbandingan konsumsi CN sebelum dan sesudah penyesuaian dengan kadar

\section{C.3. Meningkatkan Waktu Tinggal}

Percobaan laboratorium dilakukan untuk mendukung hasil analisa metode anova, dari pengujian lab diperoleh kesimpulan bahwa penambahan waktu leaching selama 6 jam, dapat meningkatkan Au sebanyak $27 \%$. perbaikan yang dilakukan dilakukan dilapangan adalah dengan melakukan pemantauan pola feeding ke dalam tangki leaching serta mengatur mill feeder dari ball mill (gambar 12-kiri) dan pompa slurry (Gambar 12-kanan) yang merupakan kunci utama waktu tinggal di tangki leaching dan CIL.

Dari hasil pengaturan ini, dari pengamatan data selama 2 bulan diperoleh hasil peningkatan waktu tinggal yang sebelumnya hanya 50 jam menjadi 61 jam (Gambar 13). Waktu tinggal slurry yang lebih lama, akan meningkatkan waktu emas dalam bijih bereaksi sehingga akan meningkatkan nilai recovery ${ }^{(3)}$.

\section{C.4. Dampak Terhadap Emas di Sand tailing dan Recovery Emas}

Dampak perbaikan dan improvement yang dilakukan selama 2 bulan disajikan dalam gambar 14 terlihat bahwa kadar emas sand tailing sebelum perbaikan adalah rata -rata 0,49 gpt (warna kuning) menjadi 0,35 gpt setelah perbaikan (warna hijau) dari target 0,39 gpt. Sedangkan gambar 15 
menunjukkan adanya dampak signifikan terhadap peningkatan \%recovery emas di $\mathrm{P} 1$, dari rata - rata sebelum perbaikan adalah $89,4 \%$ (kuning) menjadi rata - rata 92,7\% (hijau).

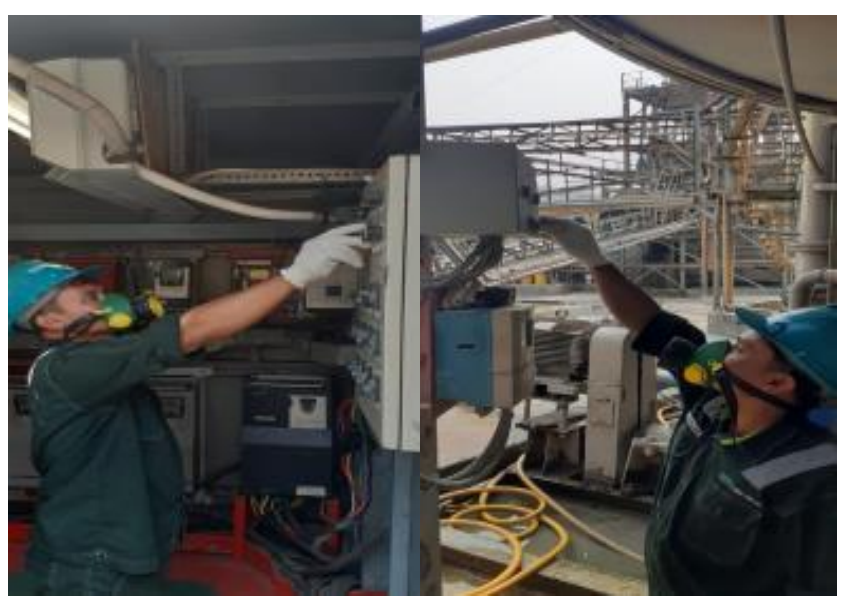

Gambar 12. Pengaturan mill feeder ballmill 01 (kiri), pengaturan flowrate pompa slurry (kanan)

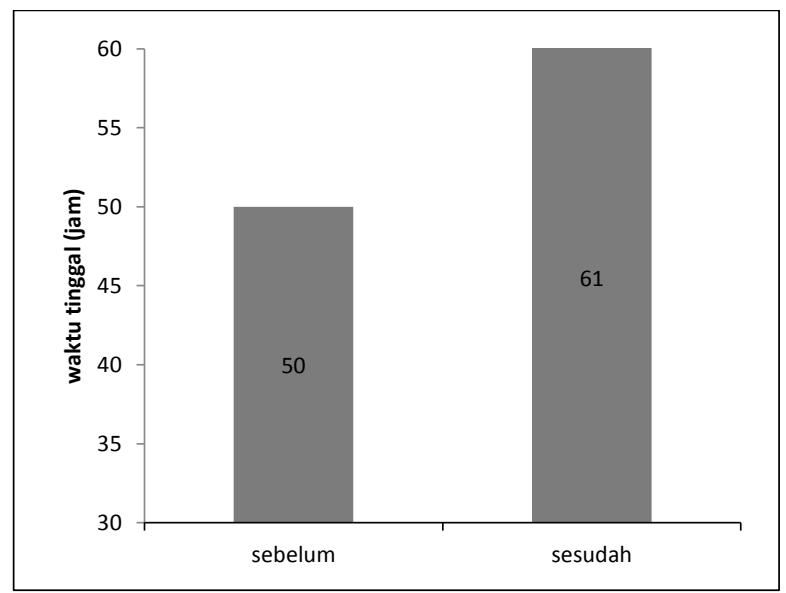

Gambar 13. Kondisi waktu tinggal slurry sebelum dan sesudah perbaikan

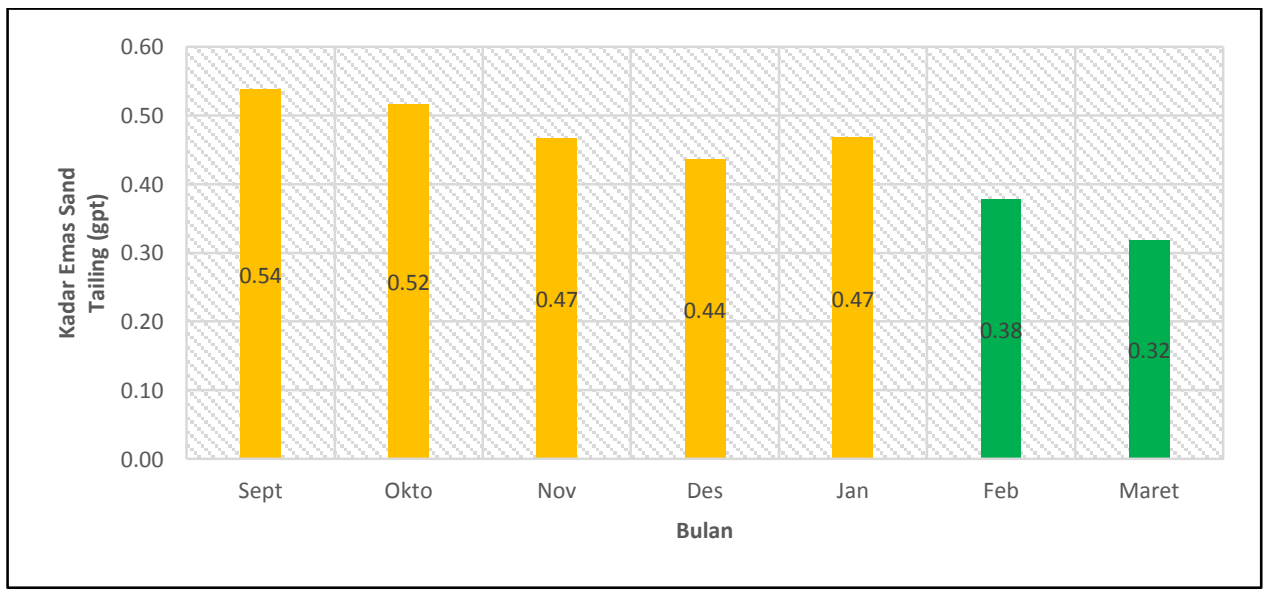

Gambar 14. Perbandingan kadar Emas di sand tailing sebelum (kuning) dan setelah (hijau) perbaikan dan improvement 


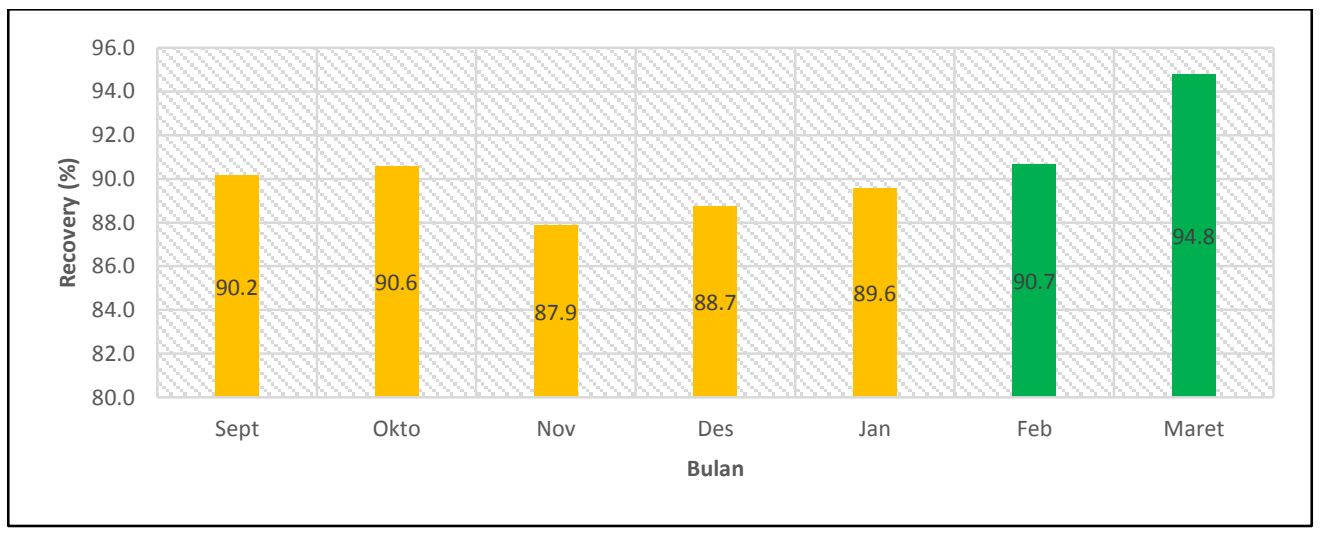

Gambar 15. Perbandingan kadar Emas di sand tailing sebelum (kuning) dan setelah (hijau) perbaikan dan improvement

\section{KESIMPULAN}

Intisari dari perbaikan dan improvement untuk meningkatkan recovery emas dari pembahasan makalah ini, yaitu:

1) Persentase recovery Plant 1 di UBPE Pongkor dapat ditingkatkan dari $89,4 \%$ menjadi $92,7 \%$.

2) Urutan faktor yang memengaruhi recovery adalah fraksi halus, kadar sianida, dan waktu tinggal slurry yang diketahui dengan melakukan uji anova

3) Perbaikan fraksi halus dapat dilakukan dengan blending bola baja, dengan perbandingan yang optimal ada $1: 2$ untuk ukuran bola $40-60 \mathrm{~mm}$ dan $60-80 \mathrm{~mm}$,

4) Penyesuaian kadar feed dan pengaturan pola feeding sianida di tangki leaching berdampak positif dari segi $\mathrm{K} 3$ (mixing hanya $1 \mathrm{x}$ untuk 1 hari) dan efisiensi bahan baku $\mathrm{NaCN}$, dari 1,23 gpt menjadi $1,13 \mathrm{gpt}$

5) Pengaturan waktu tinggal tinggal dapat dilakukan dengan mengatur pola feeding mill feeder dan pompa slurry dapat meningkatkan waktu tinggal dari 50 jam menjadi 61 jam

\section{DAFTAR PUSTAKA}

Hasanazadeh, Ahmad; Increasing Primary Grinding Circuit Efficiency considering Grinding Capacity Enhancement, Conference Paper, 2015, 3-4.

Will's, Mineral Processing Technology $7^{\text {th }}$ edition, Elsevier 2006, 100 - 120.

Levenspiel, O., Chemical Reaction Engineering $3^{\text {rd }}$ Edition, John Willey \& Sons, 1999, 55 - 60. 